\title{
Design Of Tracer Using Microsoft Access Unit In Medical Record Primary Health In Padang
}

\author{
Deni Maisa Putra ${ }^{1 *}$, Alfauzain ${ }^{2}$ \\ ${ }^{I}$ Department of Medical Record and Health Information, STIKES Dharma Landbouw, Padang, Indonesia \\ ${ }^{2}$ Department of Hospital Administration, STIKES Dharma Landbouw, Padang, Indonesia \\ *Corresponding author E-mail: denimaisaputra@gmail.com
}

Manuscript received 15 April 2021; revised 1 May 2021; accepted 15 June 2021. Date of publication 3 July 2021

Abstract

Microsoft Access (also known as Access) is an application used to process databases. The implementation of storage at the Primary Health Center is still manual if the patient's medical record file is not found on the storage shelf, the officer will make a temporary file which will cause the accumulation of files on the shelf. There is still a misplaced medical record file (Missfile) due to the absence of a tracer being stored as a control for releasing medical record files and borrowing medical record files. The purpose of this research is how to design a tracer using Microsoft Access in the medical record unit at Primary Health Center, Padang. This research is about designing a tracer in the medical record unit at Primary Health Center in Padang. This type of research is Research and Development, conducting in-depth interviews, observation, and testing at the storage area and interviews with 1 head of administration, 1 head of medical records, and 2 storage officers. This research was conducted from 25 July to 2 August 2019 at Padang Primary Health Center. Based on the research results, it was found that the identification of tracer data elements in a computerized manner was more complete in implementing the application by developing the UML (Unified Modeling Language) method, namely by using use case diagrams and activity diagrams, as well as data flow diagrams. Efficiency is obtained by means of manually, 1 and computerized 3.5 so that the tracer efficiency is more computerized while the effectiveness is in accordance with what the officers expect. The conclusion in this study found that the officers were satisfied and the application was as expected because it was easy to use. Judging from the test results, this tracer application can be used, seen from the expectations and satisfaction of the officers, the data is appropriate and can improve performance, effectiveness, and efficiency in service. Therefore, the researchers hope that this application can be implemented in services and developed again in the future.

Keywords: Microsoft Access, UML (Unified Modeling Language), Tracer System.

\section{Introduction}

The development of information technology today affects various aspects of life and profession, one of which is in the field of health services. In every health service place, every time a patient comes for treatment, the patient's identity, the results of the diagnosis of the disease by the doctor, the drugs given to the patient, and the actions taken by the doctor towards the patient are known as Medical Records. Where the Medical Record will be used as a reference for patient treatment at the next examination [1].

Patient data and information contained in medical records are very useful for the management of health care institutions to assess whether their services are of high quality, efficient and effective. The speed in providing medical record files to the poly is one of the indicators of service quality in medical records. The sooner the medical record arrives at the polyclinic, the faster the service will be obtained by the patient [2].

Storage of good medical records is one of the keys to the success or good management of a health service, of course if it is supported by a good system, quality human resources and good work procedures as well as adequate facilities and infrastructure. The availability of medical records when needed will greatly facilitate and assist in the quality of health services provided to patients quickly and accurately [3].

Some facilities in the medical record filing room in the process of receiving medical records that come out of the storage room must use an outguide or commonly called a Tracer. Outguide or Tracer is a useful and useful tool for monitoring the use of medical records. In its use, the exit instructions are placed as instructions in the medical record holder that is removed from the storage rack. The borrowed card/exit instructions remain on the shelf until the retrieved medical record is returned to its original place [4].

Based on observations to the Primary Health Center, it was found that there were still problems with the storage staff. The storage system at Primary Health Center is Straight (direct) which consists of letters and numbers. Letters describe the patient's address in 
accordance with the working area of the puskesmas and numbers describe the alignment system. The implementation of the storage at the Primary Health Care is still manual, namely the officer looks for the patient's medical record on the storage filling according to the medical record number, family name and address of the patient's origin. If the medical record is not found by the clerk on the storage shelf, the creation of a temporary file will cause a pile of files on the shelf. There are still medical records that are misplaced (Missfile) because there is no tracer stored as a control over the expenditure of medical records and the transfer of medical record files by officers and other health services.

When the file comes out of the filing rack and is borrowed by any party, it is advisable to have an Outguide as a sign that the file has left the shelf by inserting the outguide in the medical record holder taken from the storage rack. The advantage is that the tracer can prevent or minimize missfiles and facilitate the storage, retrieval and tracking of medical records. Error control can increase the speed of the medical record service process which can improve health quality standards in services to the community. From this description, the researcher is interested in Designing a Tracer with Microsoft Access Applications in the Medical Records section at Primary Health Center. This study aims to find out how to design a tracer using the Microsoft Access application in the medical record section at Primary Health Center in Padang.

\section{Literature Review}

\subsection{Tracer}

Tracer is to determine the existence of paper-based Medical Records. The medical record unit must always carry out control in accordance with the procedure for requesting and using medical records. All medical records that come out of shelves for any reason must have a tracer (exit instructions) and track / indicate the location of delivery [5].

The tracer implementation square is as follows ;

1. The registration officer writes down the medical record number, patient name, date, and loan from each medical record file used for routine purposes on a tracer sheet on the upper right side first.

2. The medical record file is taken from the storage rack, replaced with a fully filled tracer.

3. The tracer is inserted (placed) at the exact position of the outgoing file with the writing position standing.

4. The tracer is taken from the storage rack when the medical record file used is back in its place.

5. Tracer can be used repeatedly until the writing is full.

\subsection{Microsoft Access}

Microsoft Access (also known as Access) is an application used to process databases. This application has several advantages compared to other database applications in terms of ease of operation and availability of applications in the community. This application is an application package issued by Microsoft Corporation in a package called Microsoft Office [6].

The Access application, which is an application package with Microsoft Office, is the most widely used office application software in Indonesia today. Like other Microsoft, Access has an advantage in terms of interaction between the user and the computer. Users are facilitated by the various assistance facilities available in the program. To make it easier for users to run the program, a wizard facility is also provided that can be used by users when having difficulty starting to create a database ;

1. Table, to create a table in Access using the three facilities provided, namely using Design View, Wizard, and Enteriting data.

2. Query, shaped like a table and is a medium for manipulating tables

3. Form, is used as a media interface between the user and the database. Form is a window that is used to enter or perform certain actions against a table or database.

4. Report, serves as a medium for making reports for users of information in the database.

\subsection{System Analysis and Design}

System analysis and design is the first step in system development to determine needs, problems that can be overcome from the existence of a system to be built, and what kind of system will be created [7].

\subsection{Unified Modeling Language (UML)}

Unifed Modeling Language (UML) is a family of graphical notations supported by a single meta-model, which helps in the description and design of software systems, especially systems built using object-oriented programming [8].

1. Use Case Diagrams

Use case diagram is a modeling for the behavior (behavior) of the information system to be made. Use cases are used to find out what functions are in the information system and who has the right to use these functions. [8].

Table 1. Symbol-symbol Use Case Diagram

\begin{tabular}{lll}
\hline No & \multicolumn{1}{c}{ Name } & \multicolumn{1}{c}{ Information } \\
\hline 1. & Use Case & $\begin{array}{l}\text { Describes the functionality provided by the system as } \\
\text { units that exchange messages between units with } \\
\text { actors, expressed using the verb }\end{array}$ \\
\hline 3. & $\begin{array}{l}\text { An actor is an abstraction of another person or system } \\
\text { that activates the function of the target system. In } \\
\text { order to identify the actors, it is necessary to define } \\
\text { the division of labor and the tasks related to the roles } \\
\text { in the context of the target system. }\end{array}$ \\
\hline Association & $\begin{array}{l}\text { The association between the actor and the use case, } \\
\text { represented by a line without arrows indicating who } \\
\text { or what is requesting direct interaction instead of }\end{array}$
\end{tabular}




\begin{tabular}{ll} 
Collaboration & $\begin{array}{l}\text { The interaction of rules and other elements that work } \\
\text { together to provide behavior that is greater than the } \\
\text { sum and its elements (synergy). }\end{array}$ \\
\hline 6. & $\begin{array}{l}\text { include, is inside another use case (required) or a use } \\
\text { case call by another use case, an example is calling a } \\
\text { program function }\end{array}$ \\
\hline 6. & Extend
\end{tabular}

2. Activity Diagrams

Activity Diagrams describe a series of flow of activities, used to describe activities that are formed in an operation so that it can also be used for other activities. This diagram is very similar to a flowchart because it models the workflow from one activity to another, or from activity to state. Making activity diagrams at the beginning of process modeling can help understand the whole process. Activity diagrams are also used to describe the interactions between several use cases.

Table 2. Symbol-symbol Activity Diagram

\begin{tabular}{|c|c|c|c|}
\hline No & Ficture & Name & Information \\
\hline 1 & & Actifity & $\begin{array}{l}\text { Shows how each interface class interacts with each } \\
\text { other }\end{array}$ \\
\hline 2 & & Action & $\begin{array}{l}\text { State of the system that reflects the execution of an } \\
\text { action }\end{array}$ \\
\hline 3 & & Initial Node & How objects are formed or initiated. \\
\hline 4 & & $\begin{array}{c}\text { Actifity Final } \\
\text { Node }\end{array}$ & How objects are formed and destroyed \\
\hline 5 & & Fork Node & $\begin{array}{l}\text { One stream which at a certain stage turns into several } \\
\text { streams }\end{array}$ \\
\hline
\end{tabular}

3. Data Flow Diagrams (DFD)

Data Flow Diagrams (DFD) are also known as Data Flow Diagrams (DAD). DFD is a data logic model or process that is created to describe: where the data comes from, and where the data comes out of the system, where the data is stored, what processes produce the data, and the interactions between the stored data, and the processes imposed on the data. That

Table 3. Data Flow Diagram (DFD) Symbols

\begin{tabular}{ll} 
Symbol & $\begin{array}{l}\text { External Entity } \\
\text { External unit is a unit (entity) in the environment } \\
\text { outside the system which can be in the form of peo- } \\
\text { ple, organizations or other systems in the external } \\
\text { environment that will provide input or receive output } \\
\text { from the system. }\end{array}$ \\
\hline & $\begin{array}{l}\text { Data } \text { Flow } \\
\text { This data flow shows the flow of data which can be } \\
\text { input to the system or the result of the system pro- } \\
\text { cess. }\end{array}$ \\
\hline
\end{tabular}




\section{Methods}

This research method uses the Research and Development method. Respondents in this study were four people, one Head of Administration, one Head of Medical Records and two storage officers. The object of this research is the design of a tracer in the medical record storage unit. The research stages modify the development model from [9].

The stages of research and development are as follows:

1. Potential and Problems, is something that when used will have added value. While the problem is the deviation between what is expected and what happened.

2. Trial, After a product is produced, a trial will be carried out, for that testing can be carried out by Collecting information, namely collecting various information as material for planning certain products that are expected to overcome these problems.

3. Product Design, is the result of research using various Research and Development. In the field of technology, technology products that can be oriented can be used in human life including good product quality, energy saving, attractive, low price, light weight, ergonomic, and many benefits.

4. Design validation, Design validation is an activity process to assess whether the product design has been effective from the old one or not.

5. Design Improvements, Design improvements, namely if weaknesses are still found in a product, it will be done by processing the design again so that the product can be used.

6. Product experimentation, namely comparing the effectiveness and efficiency of the old work system with the new one.

7. Product revision, product trials on a small scale can show that the new system is better than the old system. From the results of testing a product, it will be seen that the comfort of employees in running the product can increase at a high gradation.

8. Usage Trial, After a successful product trial, this will allow for a new revision but it is not too important, then the product in the form of a new device is applied in real conditions for a wide scope. In the operation of the new procedure technique, it is still necessary to assess the shortcomings or obstacles that arise in order for further improvement.

9. Revision of this product is carried out, if there are real weaknesses and shortcomings in its use. In the trial, the product should be evaluated in the manufacture of the product performance system, in this case the work system.

10. Produce Mass Products, Making mass systems can be done if the results of the products that have been tested are declared effective and feasible for mass production.

\section{Results and Discussion}

Based on in-depth interviews with the Administration, the Head of Medical Records and two medical record storage officers regarding Tracer Design with the Microsoft Access application at the Medical Record unit at primary Health Center, the following results obtained:

Table 4. Conclusions in-depth interviews regarding the Planning of Tracer Application Design with Microsoft Access with Administration and Head of Room.

\begin{tabular}{lll}
\hline Interview & \multicolumn{1}{c}{ Research result } & Conclusion \\
\hline There has been no special training & There has been no special training related & Based on the results of this study, it can \\
related to medical records for & to medical records for officers who only be concluded that special training \\
officers who only have training on & have training on the Epuskesmas & related to medical records is needed for \\
the application of the health center, application, with the application it can officers, not only training on \\
and the existing facilities are make it easier for officers and more
\end{tabular}

Table 5. Conclusions in-depth interviews regarding the Tracer Application Trial in the Medical Record Storage Unit

Interview
The storage implementation is in




\subsection{System Development Method}

\subsubsection{Use Case Diagram}

The development of the method in this study was carried out using a Use Case Diagram, in which the actor in this study was the storage officer who played a role in making outgadet instructions for medical record files when borrowed by the health service. The following is a Use Case Diagram of Tracer Design with Microsoft Access application on the Medical Record unit at Primary Health Center:

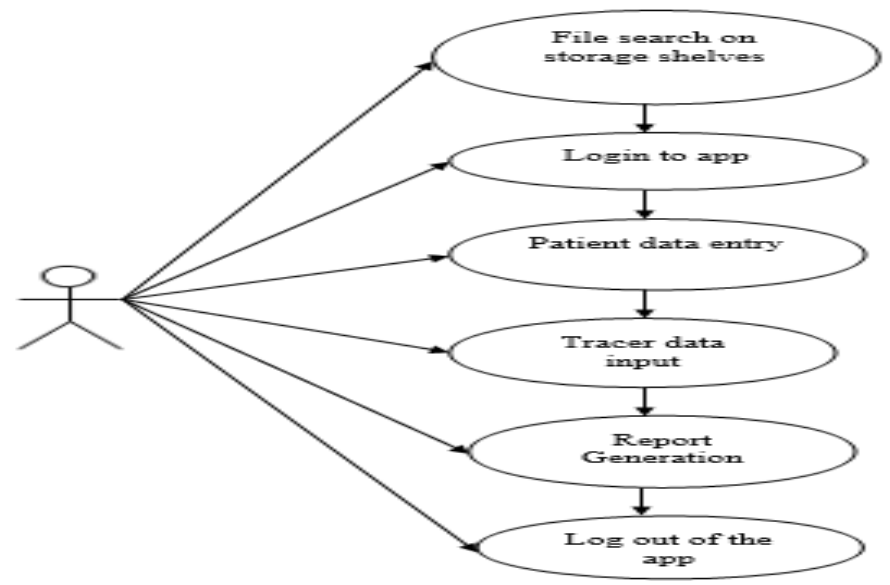

Fig 1. Use Case Diagram of the Tracer System

\subsubsection{Activity Diagram}

Activity Diagram shows the workflow (workflow) or activities of a system or business process. The point to note here is that activity diagrams depict system activities not what actors need to do. The following is an activity diagram of the tracer design with the Microsoft Access application at Primary Health Center:

a. Activity Diagram Login

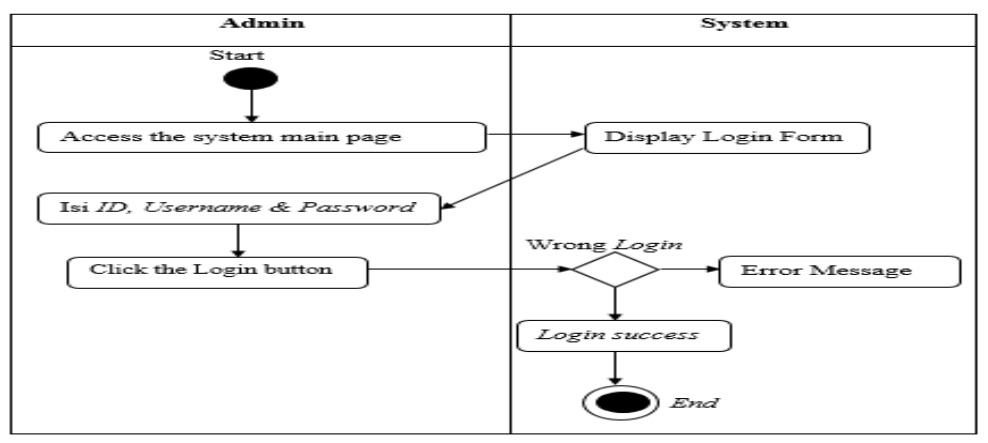

\section{b. Activity Diagram of Patient Data Input}

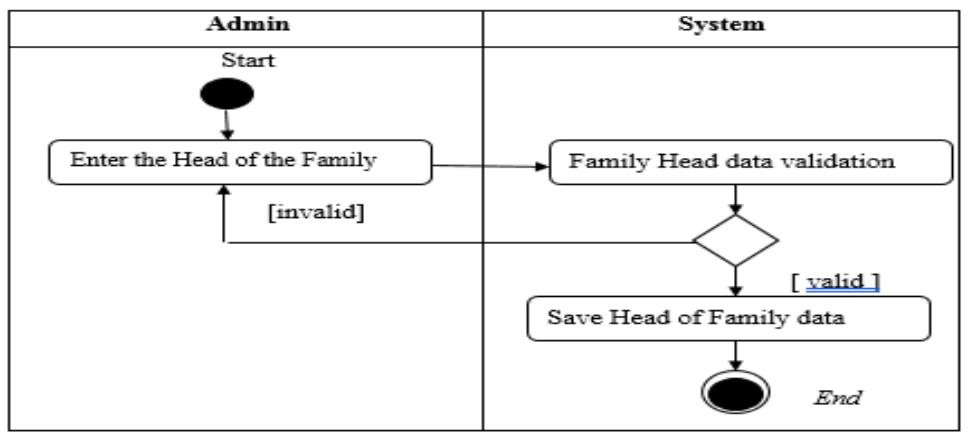


c. Activity Diagram Input Data Tracer

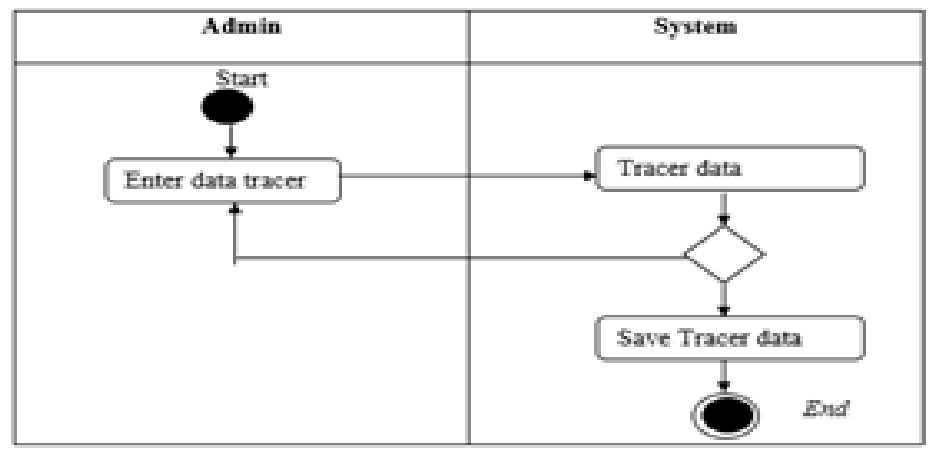

d. Activity Diagram Search Data Tracer

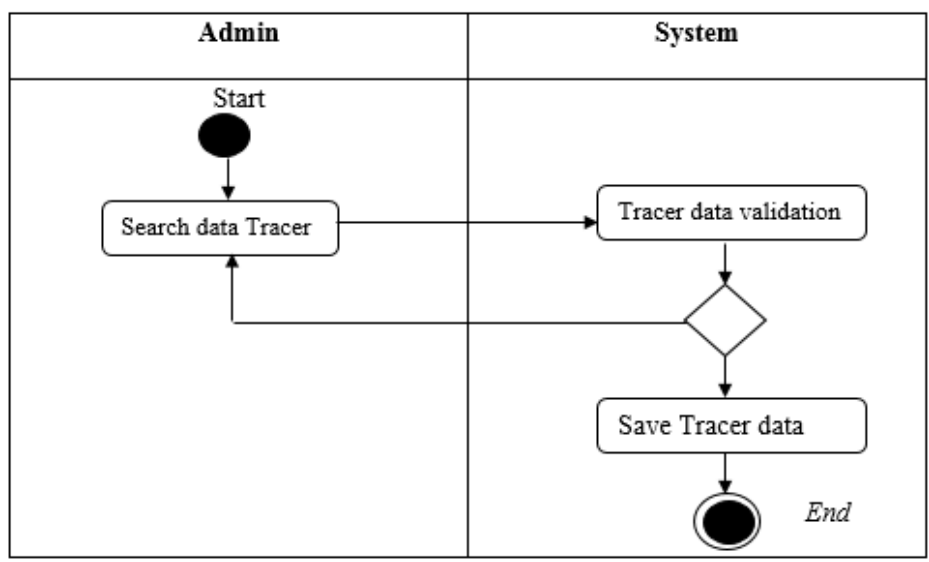

\subsection{Medical Record Tracer Application Design}

a. User Table View Design

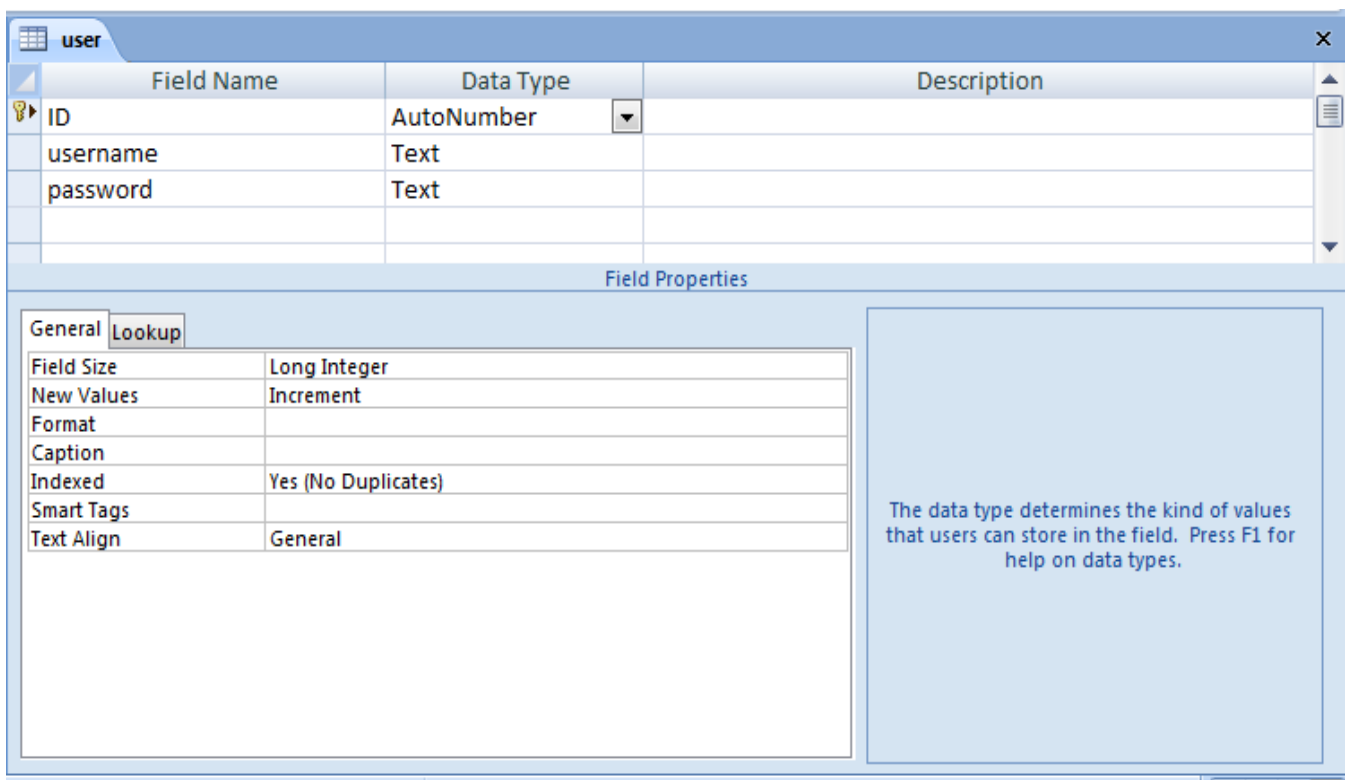




\section{b. Patient Data Table View Design}

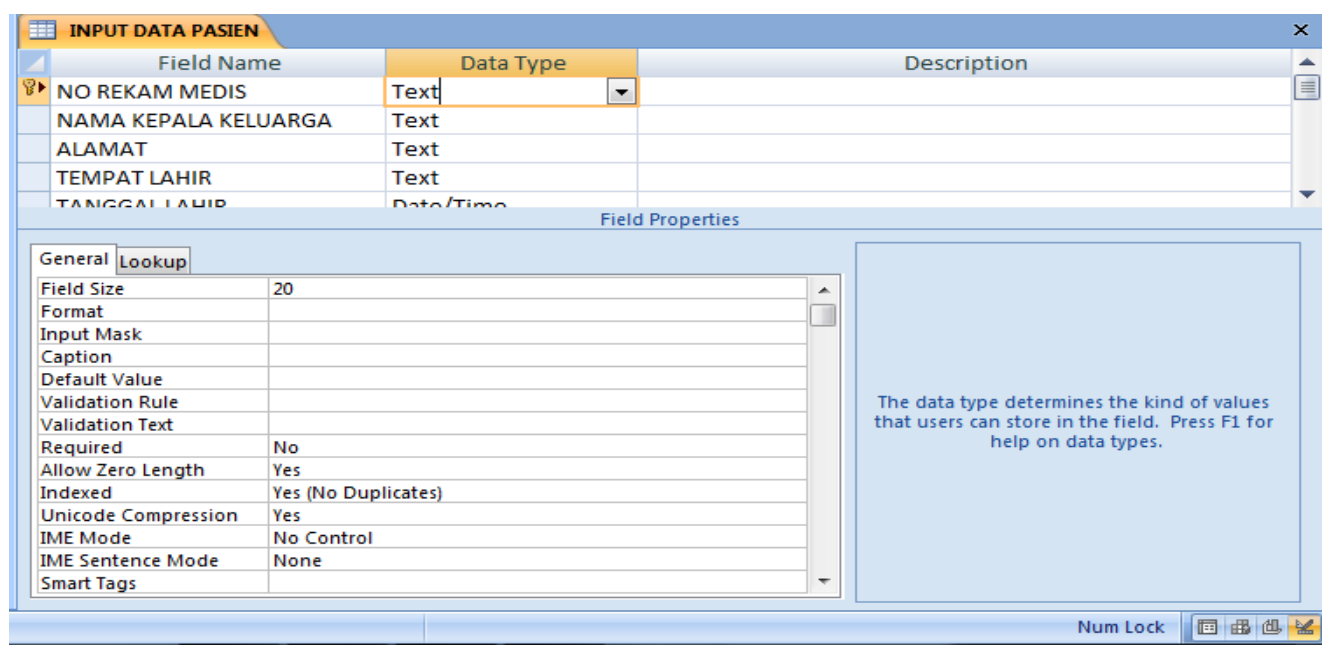

c. Data Tracer Table View Design

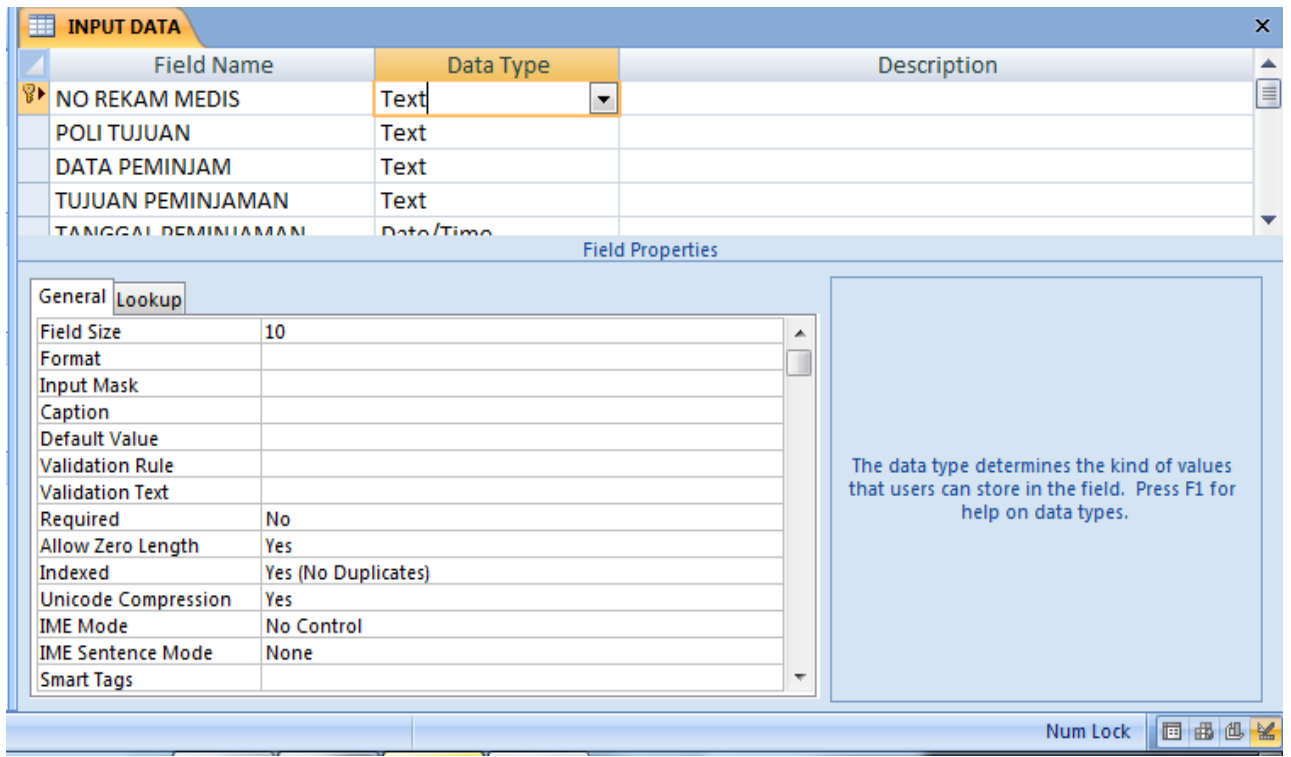

\section{d. Data tracer Query Design}

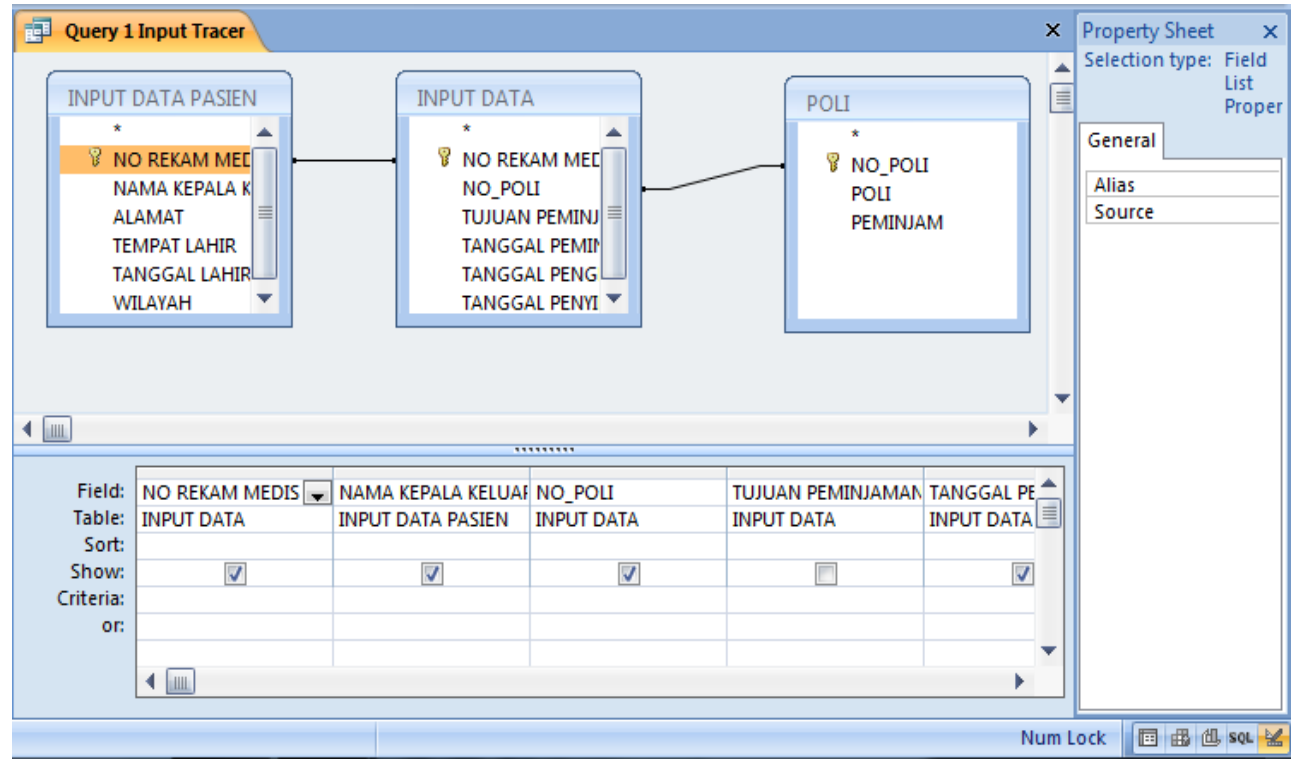




\subsection{User Form Design}

The login page is the first page after we enter the web address. The login page is used to enter the application, where there is a username and password that must be filled in by the user of the application, it will open directly to the login page in the application.

\subsubsection{Patient Data Input Form Page}

The patient data input form page in the application is a page that is used to enter patient data and the results will be stored in the database.

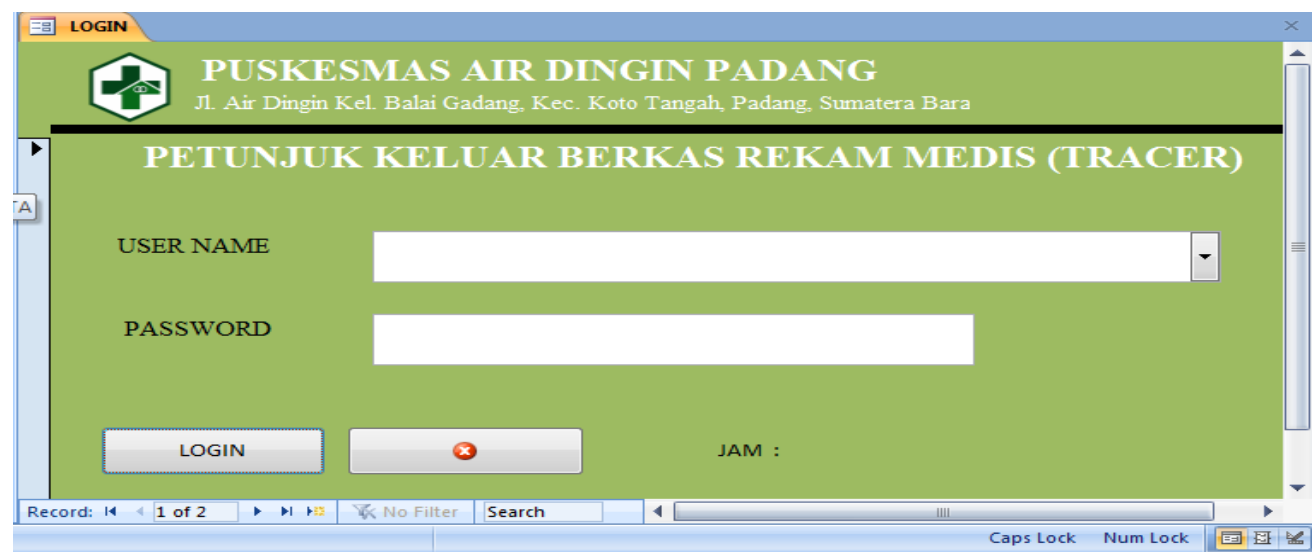

\subsubsection{The Tracer Data Input Form Page In The Application}

The tracer data input form page in the application is a page that is used to enter patient medical record loan data and the results will be stored in the database.

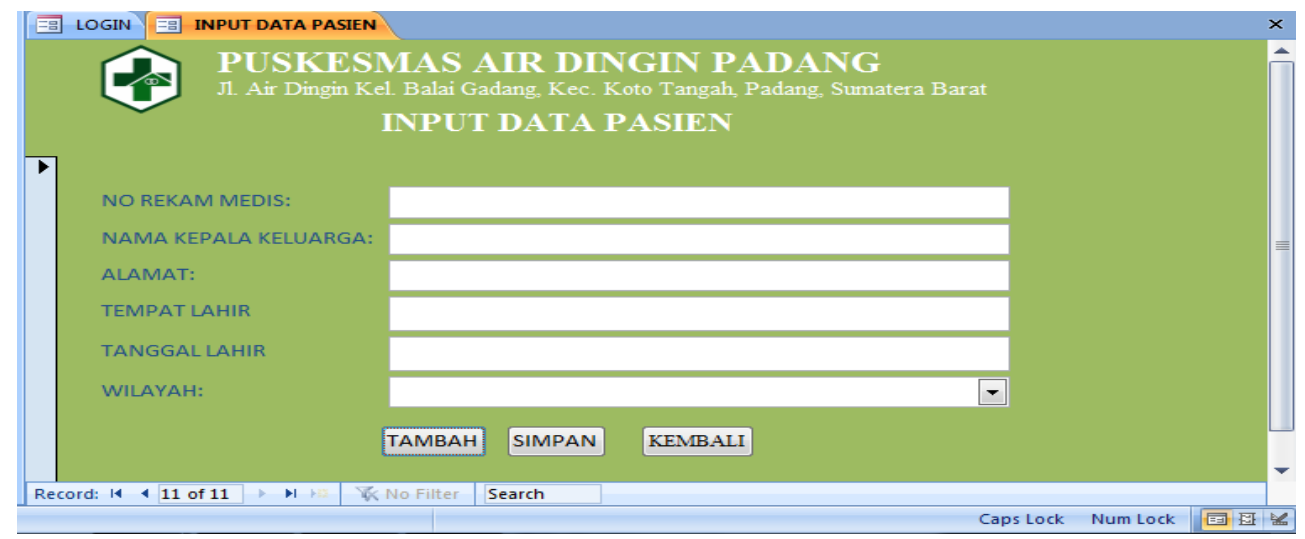

\subsubsection{Search Form Page For Tracer Data In The Application}

The search data tracer form page in the application is a page that is used to find patient data and patient file loan data and the results will be stored in the database.

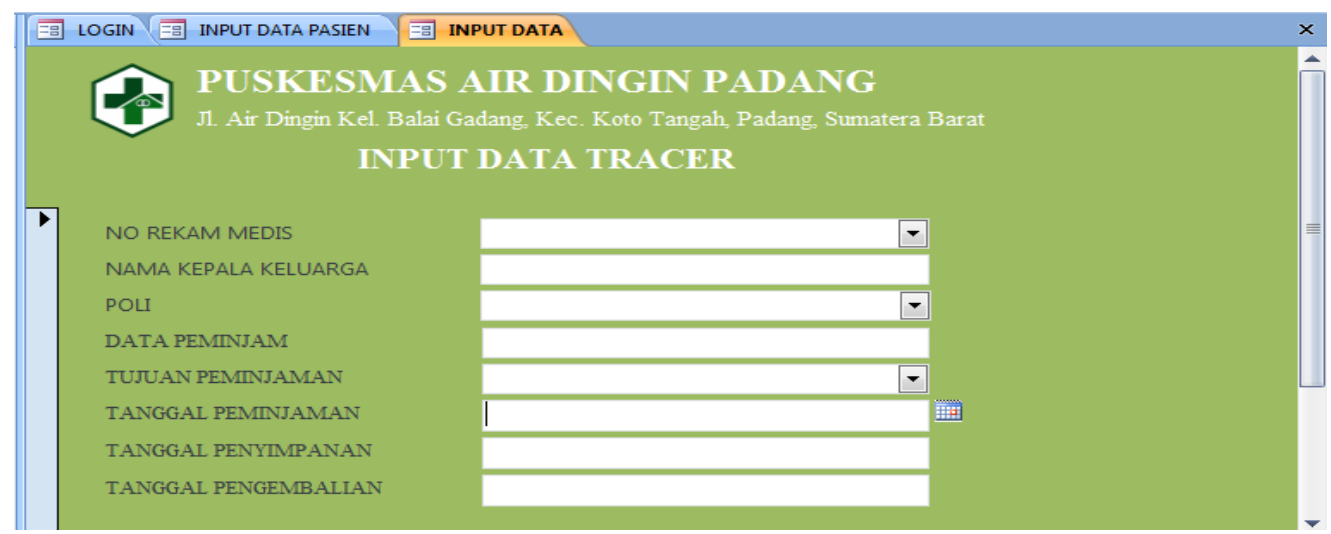


The report form page in the application is the page that is used to display the results of the patient file loan data in print out form.

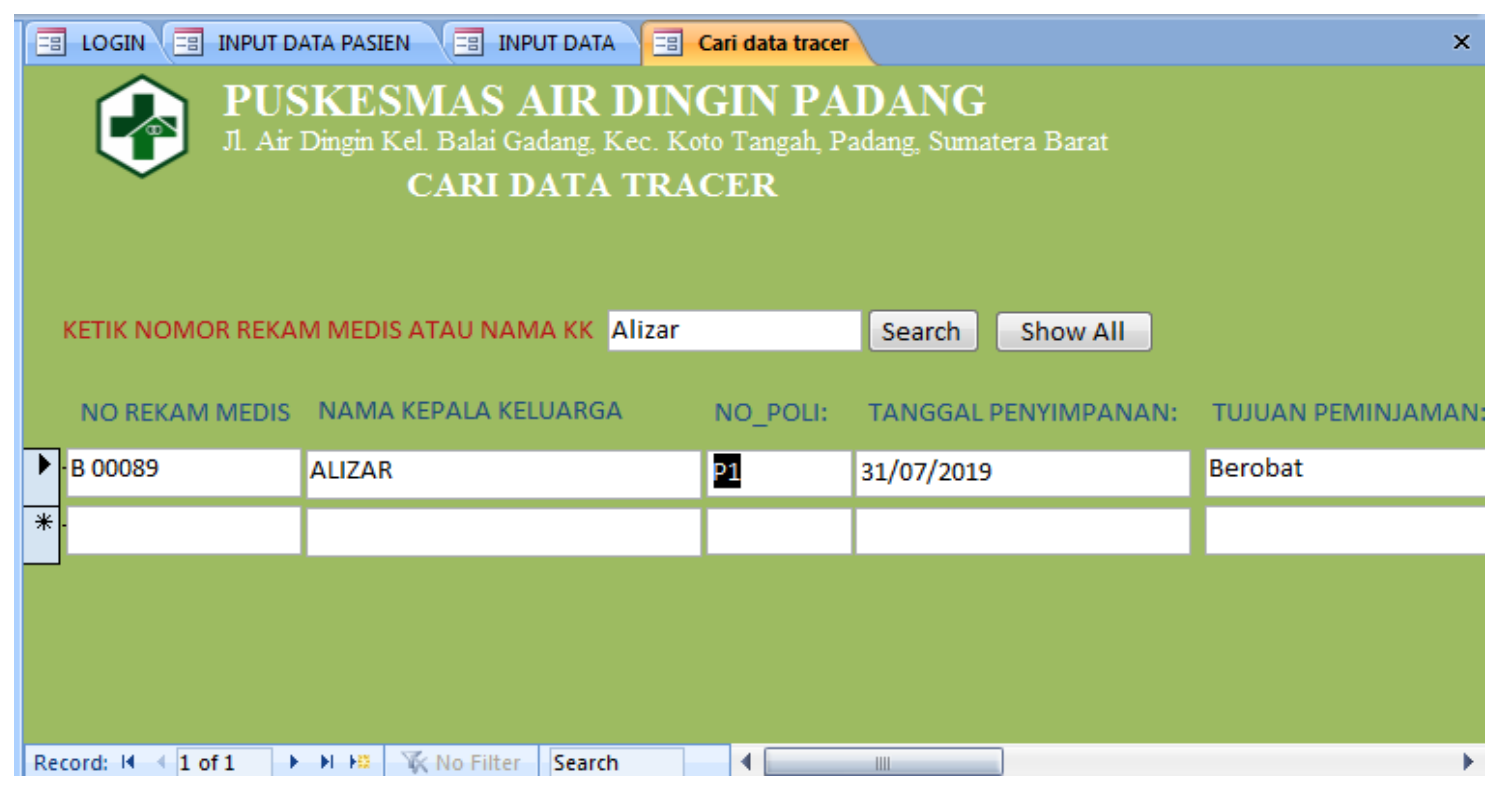

\begin{tabular}{llll}
\hline PUSKESMAS AIR DINGIN PADANG \\
J1. Air Dingin Kel. Balai Gadang. Kec. Koto Tangah, Padang. Sumatera Barat
\end{tabular}




\subsection{Discussion}

\subsection{Identify Data Tracer Elements}

Identification of tracer data elements is an activity to search for, examine and examine parts of the data contained in the medical record tracer, namely by conducting in-depth interviews with informants and observing the medical record tracer data elements in the application system that will be designed.

Tracer data elements are divided into 2, namely manual tracer data elements and computerized tracer data elements. The tracer data element according to WHO (2002), a good type of outgadet guide or tracer is in the form of a card, which is almost the same size or slightly larger than the medical record, and must include: Patient Name, Medical Record Number, Purpose of the medical record or borrower and Date Exit. While tracer data elements are computerized, namely obtained from observations and in-depth interviews with informants in the form of medical record numbers, family names, poly, borrower data, borrower goals, borrowing dates, return dates and storage dates. The results of the indepinterview obtained what data is in the tracer and is needed to design a computerized tracer application.

The advantages of computerized tracer data are that the data is more complete and the data is obtained from the results of in-depth interviews with informants, while the tracer data is obtained manually in theory.

\subsection{Database Anlysis}

The development of the application in this research is the design of a tracer with the Microsoft Access application that functions in tracking medical records and as a medical record outlet taken for any purpose, either by the poly, for research, insurance and others so that no medical records are scattered or left behind. and lost or misplaced (misfile)[10].

Planning a tracer application is very much needed at the Air Cold Health Center, the data needed are in two parts, namely patient data, tracer data and search for tracer data. Patient data is in the form of patient identity in general, while tracer data is the identity of the person who borrows medical records. For the first one, starting with patient data, the required data are Medical Record Number, KK Name, Address, Place of Birth, Date of Birth.

After that, proceed with tracer data and search for tracer data, the data needed is the same, namely Medical Record Number, KK Name, Poly, Borrower's data, purpose of borrowing, date of borrowing, date of return, date of storage.

The advantage of data analysis is that the data needed by informants has been carried out, such as the need for patient data, tracer data, search for tracer data and report tracer data. The disadvantage of data analysis is that there is still knowledge about the implementation of the tracer who does not know its use based on the existing theory.

\subsection{Application Design Planning}

Development of a tracer design with the Microsoft Access application that functions in tracking files and as medical record outlets that are borrowed for any purpose, either by poly, for research, insurance and others so that medical record files are not lost or misplaced (misfile). Each table has several fields, for example in the tracer table in the form of Medical Record Number, KK Name, Poly, Borrower Data, Borrower's Destination, borrowing date, return date, and storage date, which becomes the primary key, namely the MR Number which is used for all KK members. Each table has different fields and is adjusted to the needs of the table. The advantage of planning the application is that the required data has been obtained through in-depth interviews with informants. The drawback is that the patient data form should be added to the patient's age field, the data becomes more complete and accurate.

\subsection{Designing Tracer Applications}

Microsoft Access (also known as Access) is a device used to process databases. This application has several advantages compared to other database systems which are easy to run in the community. This application is an application package issued by Microsoft Corporation in a package called Microsoft Office [6]. The design of the tracer application is done by first grouping the database according to the need, namely for patient data and tracer data. The next step in the design procedure in Microsoft Access is to create tables, queries, forms and reports. The advantage of the application design is that the tracer application makes it easier for officers to track the existence of the RM file, both files borrowed by the poly and files that have not been returned to the medical record. While the drawback of this application is that the tracer application should be in sync with existing applications at the health center.

\subsection{Trial Against Application}

The analysis for the trial is divided into two parts, namely System Integration Testing (SIT) and User Acceptance Testing (UAT). According to [7], System-integrated testing is a test that ensures the system can carry out synchronized tasks with more than one application or accurate database. User Acceptance Testing is a test carried out by end-users where the user is a staff/employee of the company who directly interacts with the system and verified whether the existing functions have been running according to their needs/functions. In this implementation process, researchers have tested the application to determine the effectiveness of using the application, seen from the officers operating the system using SIT and UAT analysis.

Table 6. Trial Analysis Results SIT and UAT

\begin{tabular}{|c|c|c|c|}
\hline No. & Scenario & System Reaction & Results \\
\hline \multirow[t]{3}{*}{1.} & Login & & \\
\hline & Enter ID Username and Password & $\begin{array}{l}\text { 1. Checking Valid or not the data entered } \\
\text { by checking the user table }\end{array}$ & $\sqrt{ }$ \\
\hline & & 2. Enter the tracer application & $\sqrt{ }$ \\
\hline \multirow[t]{3}{*}{2.} & Patient Data Input & & \\
\hline & $\begin{array}{l}\text { - Enter patient data according to the } \\
\text { available column }\end{array}$ & $\begin{array}{l}\text { 1. Checking whether the data entered is } \\
\text { valid or not }\end{array}$ & $\sqrt{*}$ \\
\hline & $\begin{array}{cccc}\text { - Displaying } & \text { patient } & \text { data } & \text { saved } \\
\text { successfully } & & & \\
\end{array}$ & 2. Save patient data to database & $\sqrt{ }$ \\
\hline
\end{tabular}




\begin{tabular}{|c|c|c|c|}
\hline & $\begin{array}{l}\text { - Enter tracer data according to the } \\
\text { available column }\end{array}$ & $\begin{array}{l}\text { 1. Checking whether the data entered is } \\
\text { valid or not }\end{array}$ & $\sqrt{ }$ \\
\hline & $\begin{array}{cccc}\text { - Displaying } \\
\text { successfully }\end{array}$ tracer data saved & 2. Save tracer data to database & $\sqrt{ } *$ \\
\hline \multirow[t]{3}{*}{4.} & Looking for tracer data & & \\
\hline & - enter keywords and categories & 1. Select search result data & $\sqrt{ }$ \\
\hline & - perform the data search process & 2. Display Tracer Data & $\sqrt{ }$ \\
\hline \multirow[t]{3}{*}{5.} & Tracer data report & & \\
\hline & Choose the report menu & 1. Display selected tracer data & $\sqrt{ }$ \\
\hline & & 2. display all tracert data & $\sqrt{ }$ \\
\hline \multirow[t]{2}{*}{6.} & Logout & & \\
\hline & Choose the logout menu & the system logs out & $\sqrt{ }$ \\
\hline
\end{tabular}

Note:

1. $\operatorname{sign} \sqrt{ } *$ (suggestion should be added to the patient data form on the patient's age).

2. mark $\sqrt{ } *$ (suggestion from the user so that the tracer data can be synchronized to the e-puskesmas aplication).

In conclusion, from the trial process of the tracer application in storage, which was carried out by two officers during the process of running the application, there were no problems, it just needed to be added to the patient data form, namely and the tracer application should be synchronized with the Epuskesmas application, while the data was expected and desired. users are met.

\subsection{Application Usage Efficiency}

The efficiency of this application is done by entering the RM number on the data input form until the results come out on the application and the results of observations can be seen that the computerized search for files that are not found by officers is faster than manual, in table 5.9 it can be seen as many as 10 files with an average run time in searching for files not found manually, namely 6.1 seconds, while the time required in searching for files not found computerized is 3.5 seconds more efficient (time) than manual. The researcher began to calculate the time for the officer to search for medical records starting from the registration officer placing the completed file input into the distribution basket and the storage officer entering the medical record number on the computer, the computer tracer data will appear. After that the officer gave it to another officer to be delivered to the poly.

So the computerized search for files that are not found by officers is faster than manual. The advantage is that the computerized search for files that are not found is more efficient than manually. The drawback after using this computerized-based tracer is that there are still officers who are doubtful because officers still do not understand how to operate the application.

\section{CONCLUSIONS}

From the results of research conducted at Primary Health Center, it can be concluded that there is a difference between tracer elements manually and tracer data elements computerized. The flow and procedures for using the tracer have been carried out using system development using UML: Use Case Diagrams, Activity Diagrams, DFD (Data Flow Diagrams). There has been a computerized tracer application using Microsoft Access. And the use of a computerized tracer application is more efficient than manually. It is recommended that the designed application can be run continuously on the storage unit in order to improve the performance of officers. And it is better if the existing application can be connected to the existing application in the health center.

\section{References}

[1] Kausar arif. A Ambarita, "Data Processing System Web-Based Medical Record in the," IJIS-Indonesian J. Inf. Syst. J. Inf. Syst., vol. 2, no. September 2016, pp. 68-77, 2016, [Online]. Available: http://ijiswiratama.org/index.php/home/article/view/8.

[2] Deni Maisa Putra \& Dila Vadriasmi, "ANALISIS PENERAPAN SISTEM INFORMASI MANAJEMEN RUMAH SAKIT (SIMRS) DI TPPRJ MENGGUNAKAN METODE UTAUT DI RS TK.III DR. REKSODIWIRYO PADANG,” vol. 1, no. 1, pp. $10-18,2020$.

[3] E. Mardyawati and A. Akhmadi, "Pelaksanaan Sistem Penyimpanan Rekam Medis Family Folder di Puskesmas Bayan Lombok Utara," J. Kesehat. Vokasional, vol. 1, no. 1, p. 27, 2016, doi: 10.22146/jkesvo.27474.

[4] DepKes RI, Pedoman Prosedur Dan Penyelenggaraan Rekam Medis di Rumah Sakit Di Indonesia. DepKes RI Dirjen Bina Pelayanan Medik: Jakarta. 2006.

[5] DepKes RI, "Pedoman Penyelenggaraan Informasi Kesehatan di Sarana Pelayanan Kesehatan Rumah Sakit Indonesia. Dir Joktorat Jendral Bina Pelayanan Medic, Jakarta.,” 2009.

[6] L. P. Hasibuan, "Perancangan Sistem Pencatatan Penggajian Dan Pph 21 Menggunakan Microsoft Access," vol. 1, no. 1, pp. 923928, 2021.

[7] S. C. Budi, "Pentingnya Tracer Sebagai Kartu Pelacak Berkas Rekam Medis Keluar dari Rak Penyimpanan,” J. Pengabdi. Kpd. Masy. (Indonesian J. Community Engag., vol. 1, no. 1, p. 121, 2015, doi: 10.22146/jpkm.16959.

[8] K. Kawano, Y. Umemura, and Y. Kano, "Field Assessment and Inheritance of Cassava Resistance to Superelongation Disease 1," Crop Sci., vol. 23, no. 2, pp. 201-205, 1983, doi: 10.2135/cropsci1983.0011183x002300020002x.

[9] Sugiyono, "Metode Penelitian Bisnis. Bandung: Alfabeta.," 2013.

[10] D. M. Putra, "Tinjauan Pelaksanaan Kerahasiaan Rekam Medis Di Puskesmas Kuranji Padang,” vol. 6, no. 1, pp. 58-66, 2021. 